\title{
Supporting Information for Arrays for the Combinatorial Exploration of Cell Adhesion
}

\author{
Brendan P. Orner, ${ }^{\dagger}$, Ratmir Derda,${ }^{\dagger}$ Rachel L. Lewis,${ }^{\S}$ James A. Thomson, ${ }^{\S}$ \\ Laura L. Kiessling,
}

Departments of Biochemistry, ${ }^{\ddagger}$ Chemistry, ${ }^{\dagger}$ and Anatomy,${ }^{\S}$ University of Wisconsin, Madison, Wisconsin 53706

*Corresponding author. E-mail : kiessling@chem.wisc.edu

Materials: All reagents for solution phase chemical synthesis were purchased from Aldrich (Milwaukee, WI) and used without further purification with the following exception: 2,2'-azobisisobutyronitrile (AIBN) was recrystallized from acetone prior to use. Amino acids were procted with 9-fluorenylmethyloxycarbonyl (Fmoc) and 4-(2', $4^{\prime}-$ Dimethoxyphenyl-Fmoc-aminomethyl)-phenoxy (Rink amide AM) resin was used for the solid phase peptide synthesis (SPPS) and were purchased from NovaBiochem (San Diego, CA). N-Hydroxybenzotriazole (HOBt) was purchased from Advanced ChemTech (Louisville, KY). Anhydrous tetrahydrofurane (THF) was distilled from Nabenzophenone ketyl. N,N-dimethylformamide (DMF) was vacuum distilled from $4 \AA$ molecular sieves. UV-irradiation at $254 \mathrm{~nm}$ was done in a Rayonet Photochemical Chamber Reactor, Model RPR-200. Flash chromatography was performed with silica gel 60, 230-450 mesh (Sorbent Technologies). Preparative HPLC was performed on a Spectra system P2000 instrument with a UV2000 detector. Preparative HPLC conditions used: Vydac $^{\odot} 150 \mathrm{~cm}$ x $22 \mathrm{~mm} \mathrm{C}-18$ reverse-phase column flowing at $10 \mathrm{~mL} / \mathrm{min}$ using $0.1 \%$ TFA as mobile phase A and $0.1 \%$ TFA in acetonitrile as mobile phase B.

Electrospray ionization (ESI) high resolution mass spectra (HRMS) were obtained with a Micromass LCT ${ }^{\mathrm{TM}} .{ }^{1} \mathrm{H}-\mathrm{NMR}$ and ${ }^{13} \mathrm{C}-\mathrm{NMR}$ were recorded on a Bruker AC-300. The liquid chromatograph/mass spectrograph (LCMS) used was a Shimadzu LCMS-2010 instrument with photodiode array detector (SPD-M10Avp), and a single quadrupole analyzer. HPLC conditions used for LCMS were: Supelco (Bellefonte, PA) $15 \mathrm{~cm} \mathrm{X} 2.1$ $\mathrm{mm} \mathrm{C}$-18 wide-pore reverse-phase column flowing at $200 \mu \mathrm{L} / \mathrm{min}$ using $0.4 \%$ formic acid as mobile phase A and $0.2 \%$ formic acid in acetonitrile as mobile phase B. All tissue culture reagents were obtained from Gibco/Invitrogen (Carlsbad, CA). The cell lines SHSY5Y and Swiss-3T3 were obtained from American Type Culture Collection (ATCC, Manassas, VA) and were passage 20 or lower. Vector Red Alkaline Phosphatase Substrate Kit I was obtained from Vector Labs (Burlingame, CA). Glass coverslips (Corning No 1 1/2, 23 mm squares) for the array production were purchased from Fisher. 


\section{Synthesis:}
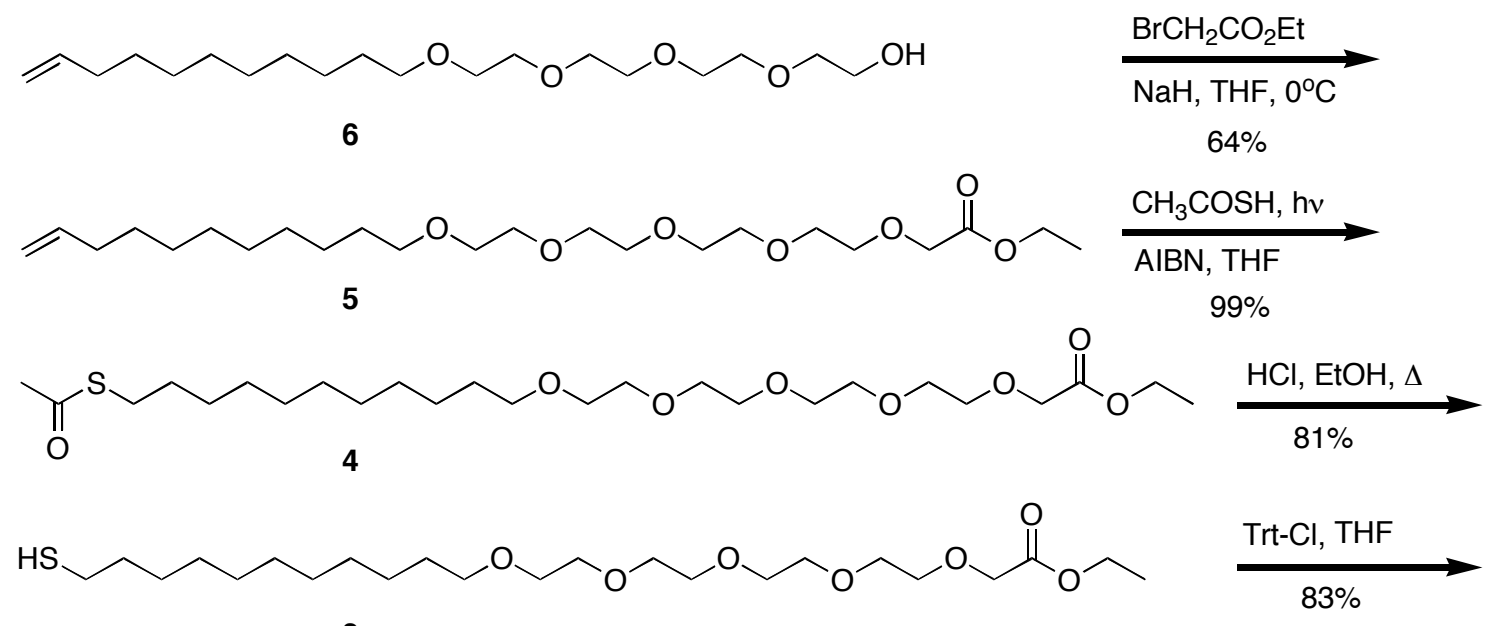

3<smiles></smiles><smiles>O=C(O)COCCOCCOCCOCCOCCCCCCCCCCCSCc1ccccc1</smiles>

1
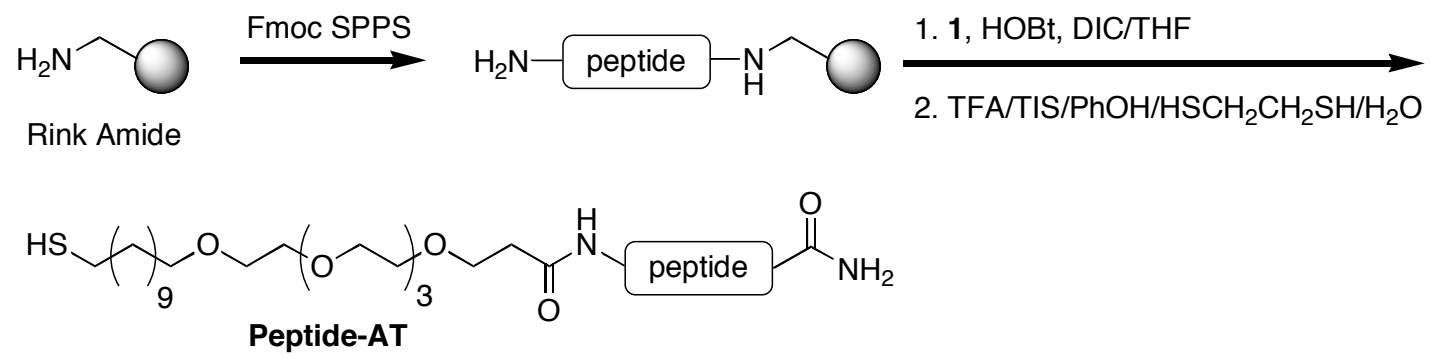

Scheme 1. Synthesis of the alkanethiol peptide conjugates. The general strategy employed was adapted from Houseman et al. ${ }^{1}$ with some modifications in the synthetic steps. In addition the tetra(ethylene glycol) derivative was employed rather than hexa(ethylene glycol). Abbreviations used: TFA, trifluoroacetic acid; TIS, triisopropylsilane; EDT, ethanedithiol; PhOH, phenol.

(2-\{2-[2-(2-Undec-10-enyloxy-ethoxy)-ethoxy]-ethoxy\}-ethoxy)-acetic acid ethyl ester (5) To a solution of compound $\mathbf{6}^{2}(3.00 \mathrm{~g}, 8.65 \mathrm{mmol})$ and vacuum-dried KI (331 $\mathrm{mg}$, $1.73 \mathrm{mmol})$ in dry THF (40 mL) was added sodium hydride (95\%, $437 \mathrm{mg}, 17.3 \mathrm{mmol})$. The solution was stirred at room temperature for $30 \mathrm{~min}$ under nitrogen and then cooled to $0{ }^{\circ} \mathrm{C}$. Ethyl bromoacetate $(2.02 \mathrm{~mL}, 17.2 \mathrm{mmol})$ was rapidly added and the reaction mixture was stirred for $3 \mathrm{~h}$ at $0{ }^{\circ} \mathrm{C}$. The reaction was quenched with $5 \%$ aqueous citric acid solution and immediately extracted with dichloromethane $(3 \times 50 \mathrm{~mL})$. The combined organic layers were washed with brine, dried over $\mathrm{MgSO}_{4}$ and concentrated with a rotatory evaporator under reduced pressure. Flash chromatography on silica gel 
$(2: 1 \rightarrow 1: 1$ hexane/ethyl acetate $\rightarrow$ ethyl acetate $)$ yielded $\mathbf{5}$ as a clear oil $(2.39 \mathrm{~g}, 5.52$ mmol, 63.8\%). ${ }^{1} \mathrm{H}$ NMR (300 MHz, $\left.\mathrm{CDCl}_{3}\right): \delta 1.23-1.41(\mathrm{~m}, 15 \mathrm{H}), 1.57$ (pent, $2 \mathrm{H}, J=7$ $\mathrm{Hz}), 1.99-2.08(\mathrm{~m}, 2 \mathrm{H}), 3.45(\mathrm{t}, 2 \mathrm{H}, J=7 \mathrm{~Hz}), 3.55-3.76(\mathrm{~m}, 18 \mathrm{H}), 4.15(\mathrm{~s}, 2 \mathrm{H}), 4.22$ (q, $2 \mathrm{H}, J=7 \mathrm{~Hz}), 4.90-5.04(\mathrm{~m}, 2 \mathrm{H}), 5.82$ (ddt, $1 \mathrm{H}, J=17 \mathrm{~Hz}, J=10.2 \mathrm{~Hz}, J=6.5 \mathrm{~Hz}) .{ }^{13} \mathrm{C}$ NMR $\left(300 \mathrm{MHz}, \mathrm{CDCl}_{3}\right): \delta 14.02,25.88,28.76,28.93,29.24,29.27,29.34,29.42,33.61$, 60.61, 68.54, 69.48, 70.40, 70.69, 71.35, 113.90, 139.03, 170.28. HRMS (ESI) calculated for $\mathrm{C}_{23} \mathrm{H}_{44} \mathrm{O}_{7} \mathrm{Na}\left(\mathrm{M}+\mathrm{Na}^{+}\right)$m/e 455.2985, found 455.2985.

[2-(2-\{2-[2-(11-Acetylsulfanyl-undecyloxy)-ethoxy]-ethoxy\}-ethoxy)-ethoxy]-acetic acid ethyl ester (4) A solution of 5 (2.37 g, $5.48 \mathrm{mmol})$, thioacetic acid (2 mL, 28.5 $\mathrm{mmol})$ and AIBN (15.0 mg, $0.09 \mathrm{mmol})$ in dry THF $(30 \mathrm{~mL})$ was purged with nitrogen for $15 \mathrm{~min}$ and the solution was irradiated at $254 \mathrm{~nm}$ for $10 \mathrm{~h}$. The reaction mixture was concentrated with a rotatory evaporator under reduced pressure and purified by silica gel flash-chromatography (eluent $2: 1 \rightarrow 1: 1$ hexane/ethyl acetate $\rightarrow$ ethyl acetate) to yield 4 as a colorless oil (2.76 g, $\left.5.44 \mathrm{mmol}, 99.3 \%) .{ }^{1} \mathrm{H} \mathrm{NMR} \mathrm{(300} \mathrm{MHz,} \mathrm{CDCl}_{3}\right): \delta 1.23-1.40$ (m, 19H), 1.50-1.62 (m, 4H), $2.32(\mathrm{~s}, 3 \mathrm{H}), 2.86(\mathrm{t}, 2 \mathrm{H}, J=7.5 \mathrm{~Hz}), 3.44(\mathrm{t}, 2 \mathrm{H}, J=7 \mathrm{~Hz})$, 3.55-3.76 (m, 18H), $4.15(\mathrm{~s}, 2 \mathrm{H}), 4.22(\mathrm{q}, 2 \mathrm{H}, J=7.5 \mathrm{~Hz}) .{ }^{13} \mathrm{C} \mathrm{NMR}\left(300 \mathrm{MHz}, \mathrm{CDCl}_{3}\right): \delta$ 14.02, 25.88, 28.61, 28.91, 28.95, 29.30, 29.35, 29.43, 30.44, 60.59, 68.53, 69.85, 70.41, 70.68, 71.33, 170.27, 195.85. HRMS (ESI) calculated for $\mathrm{C}_{25} \mathrm{H}_{48} \mathrm{O}_{8} \mathrm{SNa}\left(\mathrm{M}+\mathrm{Na}^{+}\right) \mathrm{m} / e$ 531.2963, found 531.2982.

([2-(2-\{2-[2-(11-Mercapto-undecyloxy)-ethoxy]-ethoxy\}-ethoxy)-ethoxy]-acetic acid ethyl ester) (3) A solution of $4(2.37 \mathrm{~g}, 4.66 \mathrm{mmol})$ in absolute ethanol (40 mL) was purged with nitrogen for $15 \mathrm{~min}$. An aqueous solution of concentrated $\mathrm{HCl}(4.0 \mathrm{~mL})$ was added and the resulting mixture was purged with nitrogen for another $5 \mathrm{~min}$. The reaction mixture was heated at reflux under nitrogen for $12 \mathrm{~h}$. The reaction mixture was cooled to room temperature and quenched with $1 \mathrm{M} \mathrm{NaOH}$ until the $\mathrm{pH}$ of the solution was slightly acidic. The solution was partially concentrated, diluted with water/brine (1:1) $(30 \mathrm{~mL})$ and extracted with dichloromethane $(3 \times 50 \mathrm{~mL})$. The combined organic layers were concentrated with a rotatory evaporator under reduced pressure and purified by silica gel flash-chromatography (eluent $2: 1 \rightarrow 1: 1$ hexane/ethyl acetate $\rightarrow$ ethyl acetate) to yield $\mathbf{3}$ as a colorless oil $(1.77 \mathrm{~g}, 3.79 \mathrm{mmol}, 81.4 \%) .{ }^{1} \mathrm{H}$ NMR $\left(300 \mathrm{MHz}, \mathrm{CDCl}_{3}\right): 1.22-1.42$ (m, $19 \mathrm{H}), 1.51-1.66(\mathrm{~m}, 4 \mathrm{H}), 2.52(\mathrm{q}, 2 \mathrm{H}, J=7.5 \mathrm{~Hz}), 3.44(\mathrm{t}, 2 \mathrm{H}, J=7.0 \mathrm{~Hz}), 3.55-3.76(\mathrm{~m}$, $18 \mathrm{H}), 4.15$ (s, 2H), 4.21 (q, 2H, J=1.7 Hz). ${ }^{13} \mathrm{C} \mathrm{NMR} \mathrm{(300} \mathrm{MHz,} \mathrm{CDCl}_{3}$ ): $\delta$ 14.05, 24.45, 25.87, 28.17, 28.86, 29.29, 29.35, 29.43, 33.85, 60.59, 68.52, 69.84, 70.40, 70.68, 71.33, 170.24. HRMS (ESI) calculated for $\mathrm{C}_{23} \mathrm{H}_{46} \mathrm{O}_{7} \mathrm{SNa}\left(\mathrm{M}+\mathrm{Na}^{+}\right)$m/e 489.2862, found 489.2844 .

([2-(2-\{2-[2-(11-Tritylsulfanyl-undecyloxy)-ethoxy]-ethoxy\}-ethoxy)-ethoxy]-acetic acid ethyl ester) (2) To a solution of $\mathbf{3}(1.75 \mathrm{~g}, 3.75 \mathrm{mmol})$ in dry THF (10 mL) was added trityl chloride $(2.09 \mathrm{~g}, 7.50 \mathrm{mmol})$. The reaction mixture was stirred at room temperature until complete disappearance of $\mathbf{3}$ as determined by NMR (quartet at 2.5 ppm). The reaction mixture was concentrated with a rotatory evaporator under reduced pressure and purified by silica gel flash-chromatography (eluent: $2: 1 \rightarrow 1: 1 \rightarrow 1: 2$ hexane/ethyl acetate) to yield 2 as a clear oil $(2.21 \mathrm{~g}, 3.11 \mathrm{mmol}, 83.2 \%)$. ${ }^{1} \mathrm{H}$ NMR (300 $\mathrm{MHz} \mathrm{CDCl}_{3}$ ): $\delta$ 1.08-1.44 (m, 19H), 1.56 (pent, 2H, $J=7 \mathrm{~Hz}$ ), 2.12 (t, 2H, $J=7.3 \mathrm{~Hz}$ ), 3.44 
(t, 2H, $J=7 \mathrm{~Hz}), 3.55-3.72(\mathrm{~m} \mathrm{16H}), 4.14(\mathrm{~s}, 2 \mathrm{H}), 4.21$ (q, 2H, $J=7.1 \mathrm{~Hz}), 7.16-7.31$ (m, 9H), 7.38-7.44 (m, 6H). ${ }^{13} \mathrm{C}$ NMR $\left(300 \mathrm{MHz} \mathrm{CDCl}_{3}\right): \delta 14.44,26.30,28.80,29.23$, 29.40, 29.62, 29.71, 29.77, 29.85, 32.24, 61.02, 68.94, 70.26, 70.82, 71.10, 71.76, 76.82, 77.24, 77.67, 126.69, 128.00, 129.80, 145.28. HRMS (ESI) calculated for $\mathrm{C}_{42} \mathrm{H}_{60} \mathrm{O}_{7} \mathrm{SNa}$ $\left(\mathrm{M}+\mathrm{Na}^{+}\right) \mathrm{m} / \mathrm{e}$ 731.3957, found 731.3936.

([2-(2-\{2-[2-(11-Tritylsulfanyl-undecyloxy)-ethoxy]-ethoxy\}-ethoxy)-ethoxy]-acetic acid) (1) To a solution of $2(1.63 \mathrm{~g}, 2.30 \mathrm{mmol})$ in $1: 1 \mathrm{THF} / \mathrm{MeOH}(50 \mathrm{~mL})$ was added water $(2 \mathrm{~mL})$ and solid lithium hydroxide $(193 \mathrm{mg}, 4.60 \mathrm{mmol})$. The solution was purged with nitrogen for $10 \mathrm{~min}$ and stirred at room temperature for $12 \mathrm{~h}$. The solution was acidified to $\mathrm{pH} 1$ with $1 \mathrm{~N} \mathrm{HCl}$, diluted with water/brine (1:1) $(20 \mathrm{~mL})$ and immediately extracted with dichloromethane $(4 \times 50 \mathrm{~mL})$. The combined organic layers were washed with brine $(20 \mathrm{~mL})$, dried over $\mathrm{MgSO}_{4}$ and concentrated to afford 1 as a clear oil (1.526 g, $2.24 \mathrm{mmol}, 97.6 \%) .{ }^{1} \mathrm{H}$ NMR $\left(300 \mathrm{MHz}, \mathrm{CDCl}_{3}\right): \delta 1.16-1.45(\mathrm{~m}, 16 \mathrm{H}), 1.57$ (pent, $2 \mathrm{H}, J=7 \mathrm{~Hz}), 2.13(\mathrm{t}, 2 \mathrm{H}, J=7.2 \mathrm{~Hz}), 3.45(\mathrm{t}, 2 \mathrm{H}, J=6.8 \mathrm{~Hz}), 3.57-3.78(\mathrm{~m}, 14 \mathrm{H}), 4.16(\mathrm{~s}$, 2H), 7.17-7.31 (m, 9H), 7.39-7.44 (m, 6H). $\left.{ }^{13} \mathrm{C} \mathrm{NMR} \mathrm{(300} \mathrm{MHz,} \mathrm{CDCl}_{3}\right): \delta 26.25,28.79$, 29.22, 29.40, 29.61, 29.70, 29.74, 32.23, 69.34, 70.10, 70,50, 70.58, 70.61, 70.74, 70.85, 71.56, 71.76, 126.67, 127.98, 129.80, 145.27. HRMS (ESI) calculated for $\mathrm{C}_{40} \mathrm{H}_{56} \mathrm{O}_{7} \mathrm{SNa}$ $\left(\mathrm{M}+\mathrm{Na}^{+}\right) \mathrm{m} / \mathrm{e}$ 703.364, found 703.3653.

Peptide-ATs. Peptides were synthesized on a Pioneer ${ }^{\mathrm{TM}}$ Peptide Synthesis System using standard Fmoc chemistry on Rink Amide AM resin (loading: $0.56 \mathrm{mmol} / \mathrm{g}$ ). Peptidealkanethiol conjugates were prepared similarly to the procedure of Houseman et al. ${ }^{4}$ Briefly, resin containing protected peptide with a free N-terminus was swollen in dry THF, 5-fold excess of each of the compound 1, HOBt and 1,3-diisopropylcarbodiimide (DIC) was added to the resin suspension in THF. The resin was incubated for $12 \mathrm{~h}$ and another 3-fold excess of DIC and HOBt was added. After $3 \mathrm{~h}$ the resin was tested with Kaiser test, washed with DMF and dichloromethane and dried in vacuo. After cleavage with TFA/DIC/EDT/ $\mathrm{H}_{2} \mathrm{O} /$ phenol (36:1:1:1:1) for $2 \mathrm{~h}$ and ether precipitation, conjugates were purified by preparative HPLC. Gradient used (percentage of mobile phase A): $100 \rightarrow 0 \% 20 \mathrm{~min}, 0 \% 3 \mathrm{~min} .0 \rightarrow 100 \% 3 \mathrm{~min}$. Peaks at retention time around $17 \mathrm{~min}$ were collected. Each purified sample was analyzed by LCMS and ${ }^{1} \mathrm{H}$ NMR. Note: The presence of triplet of 1,1,1-triples $\delta 2.49\left(\mathrm{t}[111 \mathrm{t}], 2 \mathrm{H}, J=7.1 \mathrm{~Hz}, J_{\mathrm{HD}}=1.0 \mathrm{~Hz}\right)$ in ${ }^{1} \mathrm{H} \mathrm{NMR}$ of AT-peptides in $\mathrm{CD}_{3} \mathrm{OD}$ is indicative of free thiol functionality. It is the signal of methylene hydrogens next to the free thiol functionality $(7 \mathrm{~Hz}$, coupling to neighboring methylene, $1 \mathrm{~Hz}$ coupling to deuterium on free thiol).

Peptide-AT (GRGDS): ${ }^{1} \mathrm{H}$ NMR $\left(300 \mathrm{MHz}, \mathrm{CD}_{3} \mathrm{OD}\right): \delta 1.27-1.45(\mathrm{~m}, 15 \mathrm{H}), 1.51-2.00$ $(\mathrm{m}, 11 \mathrm{H}), 2.49\left(\mathrm{t}[111 \mathrm{t}], 2 \mathrm{H}, J=7.1,1.0 \mathrm{~Hz},-\mathrm{CH}_{2} \mathrm{CH}_{2} \mathrm{SD}\right.$ ), 2.86 (ABX-quartet, $\mathrm{A}=2.93$ ppm, B=2.80 ppm, $\left.J_{\mathrm{AB}}=17 \mathrm{~Hz}, J_{\mathrm{BX}}=7.6 \mathrm{~Hz}, J_{\mathrm{AX}}=7.6 \mathrm{~Hz}\right), 3.21(\mathrm{t}, 2 \mathrm{H}, J=6.8 \mathrm{~Hz}), 3.47(\mathrm{t}$, $2 \mathrm{H}, J=6.7 \mathrm{~Hz}), 3.55-3.76(\mathrm{~m}, 18 \mathrm{H}), 3.8-3.94(\mathrm{~m}, 4 \mathrm{H}), 3.98(\mathrm{~s}, 2 \mathrm{H}), 4.07$ (s, 2H), 4.34$4.41(\mathrm{~m}, 2 \mathrm{H}), 4.74(\mathrm{t}, 1 \mathrm{H}, J=6.7 \mathrm{~Hz})$. HRMS (ESI) calculated for $\mathrm{C}_{38} \mathrm{H}_{71} \mathrm{~N}_{9} \mathrm{O}_{14} \mathrm{SNa}$ $\left(\mathrm{M}+\mathrm{Na}^{+}\right)$m/e 932.4739 measured 932.4740.

Peptide-AT (GKGDS) ${ }^{1} \mathrm{H}$ NMR (300 MHz, CD $\mathrm{OD}$ ): $\delta$ 1.25-1.43 (m, 15H), 1.43-1.98 $(\mathrm{m}, 11 \mathrm{H}), 2.49\left(\mathrm{t}[111 \mathrm{t}], 2 \mathrm{H}, J=7.1 \mathrm{~Hz}, J_{\mathrm{HD}}=1.0 \mathrm{~Hz},-\mathrm{CH}_{2} \mathrm{CH}_{2} \mathrm{SD}\right), 2.73-2.83(\mathrm{~m}, 1 \mathrm{H})$, 2.89-2.99 (m, 3H), 3.47 (t, 2H, J=6.7 Hz), 3.55-3.76 (m, 18H), 3.8-3.94 (m, 4H), 3.96 (s, 
2H), $4.08(\mathrm{~s}, 2 \mathrm{H}), 4.34-4.41(\mathrm{~m}, 2 \mathrm{H}), 4.73(\mathrm{t}, 1 \mathrm{H}, J=6.7 \mathrm{~Hz})$. MS (LCMS) calculated for $\mathrm{C}_{38} \mathrm{H}_{72} \mathrm{~N}_{7} \mathrm{O}_{14} \mathrm{~S}\left(\mathrm{M}+\mathrm{H}^{+}\right)$m/e 882.48 measured 882.30

Peptide-AT (GSDPGYIGSR): ${ }^{1} \mathrm{H}$ NMR $\left(300 \mathrm{MHz}, \mathrm{CD}_{3} \mathrm{OD}\right): \delta 0.87-0.97(\mathrm{~m}, 7 \mathrm{H}) 1.27-$

$1.47(\mathrm{~m}, 21 \mathrm{H}), 1.48-2.13(\mathrm{~m}, 17 \mathrm{H}), 2.49\left(\mathrm{t}[111 \mathrm{t}], 2 \mathrm{H}, J=7.1 \mathrm{~Hz}, J_{\mathrm{HD}}=1.0 \mathrm{~Hz},-\right.$

$\left.\mathrm{CH}_{2} \mathrm{CH}_{2} \mathrm{SD}\right), 2.65-2.77(\mathrm{~m}, 1 \mathrm{H}), 2.94-3.24(\mathrm{~m}, 6 \mathrm{H}), 3.46(\mathrm{t}, 2 \mathrm{H}, J=6.7 \mathrm{~Hz}), 3.54-3.74(\mathrm{~m}$, $18 \mathrm{H}), 3.74-4.08(\mathrm{~m}, 15 \mathrm{H}), 4.31-4.52(\mathrm{~m}, 5 \mathrm{H}) 4.98-5.07(\mathrm{~m}, 1 \mathrm{H}), 6.7(\mathrm{~d}, 2 \mathrm{H}, J=8.6 \mathrm{~Hz})$, $7.06(\mathrm{~d}, 2 \mathrm{H}, J=8.6 \mathrm{~Hz}), 7.91-8.46(\mathrm{~m}, 3 \mathrm{H})$. MS (LCMS) calculated for $\mathrm{C}_{63} \mathrm{H}_{108} \mathrm{~N}_{14} \mathrm{O}_{21} \mathrm{~S}$ $\left(\mathrm{M}+2 \mathrm{H}^{+}\right) \mathrm{m} / \mathrm{e} 714.35$, found 714.40

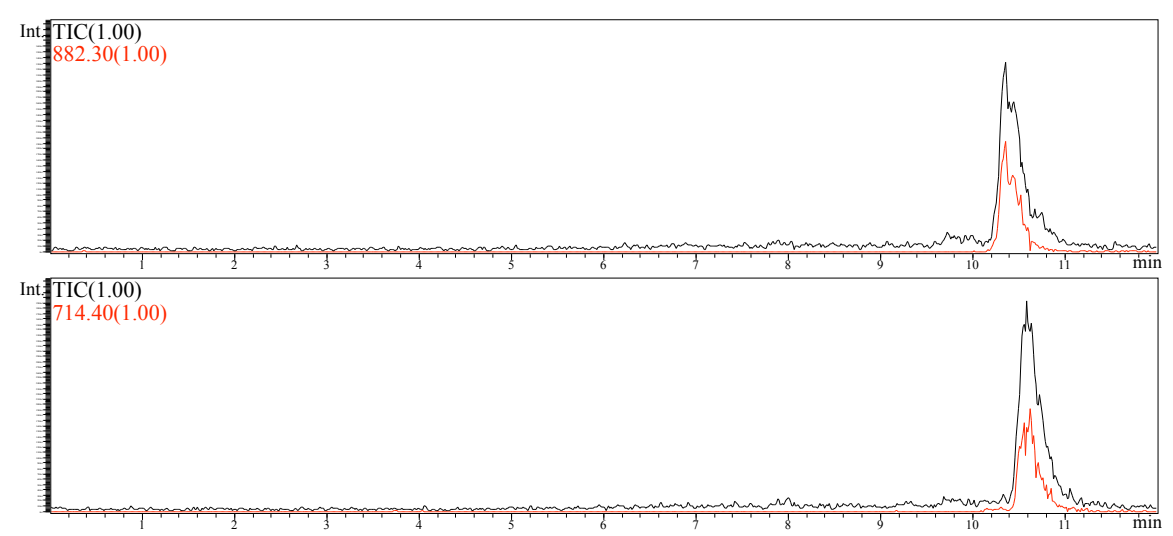

Figure S1. LCMS traces for peptide-ATs. TOP: GKFDS conjugate BOTTOM: GSDPGYIGSR conjugate.<smiles>C=CCCCCCCCCC(=O)Cl</smiles><smiles>COC(=O)ON</smiles><smiles>CN(CC(O)C(O)C(O)C(O)CO)C(=O)CCCCCCCCCC(=O)O[Ga]</smiles><smiles>O=C(O)COCCOCCOCCOCCOCCCCCCCCCCCS</smiles>

Scheme 2. Synthesis of the polyol-AT and PEG acid-AT.

(Undec-10-enoic acid methyl-(2,3,4,5,6-pentahydroxy-hexyl)-amide) (8) To a solution of N-hydroxy succinimide (NHS) in dry THF (30 mL) triethylamine $(1.03 \mathrm{~mL}, 7.38$ 
mmol) was added and the reaction mixture was cooled to $0{ }^{\circ} \mathrm{C}$. Undecenoyl chloride (944 $\mu \mathrm{L}, 4.93 \mathrm{mmol}$ ) was added dropwise. The reaction mixture was warmed slowly to room temperature and stirred for $1 \mathrm{~h}$. The reaction was quenched with $5 \%$ citric acid $(100 \mathrm{~mL})$, dichloromethane $(100 \mathrm{~mL})$ was added, the organic layer was separated, washed with brine, dried over $\mathrm{MgSO}_{4}$ and concentrated to afford undecenoyl-HNS-ester which was used without further purification. The undecenoyl-NHS-ester was dissolved in amine-free DMF (20 mL) and N-methyl glucamine $(0.963 \mathrm{~g}, 4.93 \mathrm{mmol})$ was added. The reaction mixture was stirred vigorously at room temperature for $4 \mathrm{~h}$. (N-methyl glucamine dissolves slowly during the reaction). DMF was removed with a rotatory evaporator under reduced pressure to dryness and further eliminated in vacuo and the reaction mixture was purified by silica gel chromatography (eluent $5 \% \rightarrow 7 \% \rightarrow 10 \%$ methanol in dichloromethane) to yield 8 as a white solid (1.17 g, $3.23 \mathrm{mmol}, 65.7 \%)$. ${ }^{1} \mathrm{H}$ NMR (300 $\left.\mathrm{MHz}, \mathrm{CD}_{3} \mathrm{OD}\right): \delta 1.28-1.43(\mathrm{~m}, 10 \mathrm{H}), 1.54-1.67(\mathrm{q}, 2 \mathrm{H}, J=7 \mathrm{~Hz}), 2.39$ (t, 1.1H, J=7.6 $\mathrm{Hz}), 2.48(\mathrm{t}, 0.9 \mathrm{H}, J=7.6 \mathrm{~Hz}), 2.86(\mathrm{t}, 2 \mathrm{H}, J=7.5 \mathrm{~Hz}), 2.96(\mathrm{~s}, 1.4 \mathrm{H}), 3.14(\mathrm{~s}, 1.6 \mathrm{H}), 3.34-$ $3.46(\mathrm{~m}, 1 \mathrm{H}), 3.56-3.81(\mathrm{~m}, 6 \mathrm{H}), 3.94-4.00(\mathrm{~m}, 1 \mathrm{H}), 4.88-5.02(\mathrm{~m}, 2 \mathrm{H}), 5.80$ (ddt, $1 \mathrm{H}, J=$ $17 \mathrm{~Hz}, J=10.2 \mathrm{~Hz}, J=6.6 \mathrm{~Hz}) .{ }^{13} \mathrm{C}$ NMR $\left(300 \mathrm{MHz}, \mathrm{CD}_{3} \mathrm{OD}\right): \delta 26.35,26.43,26.78$, $30.26,30.34,30.61,30.67,34.21,34.59,34.72$, 35.04, 38.13, 52.69, 54.03, 64.88, 71.28, $71.70,71.41,73.04,73.11,73.20,73.73,74.26,114.85,140.27,176.76$. Note: all NMR spectra of the polyol-AT and its precursors are complicated by slow rotation around the secondary amide bond. The signals of nuclei close to the amide bond are split into two signals in roughly a 0.88 to 1.0 ratio. For example signals $2.96(\mathrm{~s}, 1.4 \mathrm{H})$ and 3.14 (s, $1.6 \mathrm{H})$ corresponding to the $\mathrm{N}$-methyl group in the cis- and trans-amide bond conformations. HRMS (ESI) calculated for $\mathrm{C}_{18} \mathrm{H}_{35} \mathrm{O}_{6} \mathrm{NNa}\left(\mathrm{M}+\mathrm{Na}^{+}\right) \mathrm{m} / e$ 384.2362, found 384.2372 .

Thioacetic acid S-\{10-[methyl-(2,3,4,5,6-pentahydroxy-hexyl)-carbamoyl]-decyl\} ester (7) A solution of compound 8 (1.14 g, $3.15 \mathrm{mmol})$, thioacetic acid (1.00 mL, 14.3 mmol) and AIBN (15.0 mg, $0.090 \mathrm{mmol})$ in dry THF (100 mL) was purged with nitrogen for 15 minutes and reaction mixture was irradiated at $254 \mathrm{~nm}$ for $10 \mathrm{~h}$. Solvent was removed with a rotatory evaporator under reduced pressure and the reaction mixture was purified by silica gel chromatography (eluent $5 \% \rightarrow 7 \% \rightarrow 10 \% \rightarrow 15 \%$ methanol in dichloromethane) to yield 7 as a white solid (1.25 g, $2.85 \mathrm{mmol}, 90.6 \%)$. ${ }^{1} \mathrm{H}$ NMR (300 $\left.\mathrm{MHz}, \mathrm{CD}_{3} \mathrm{OD}\right): \delta$ 1.27-1.40 (m, 12H), 1.50-1.65 (m, 4H), $2.30(\mathrm{~s}, 3 \mathrm{H}), 2.39(\mathrm{t}, 1.1 \mathrm{H}$, $J=7.6 \mathrm{~Hz}), 2.48(\mathrm{t}, 0.9 \mathrm{H}, J=7.6 \mathrm{~Hz}), 2.86(\mathrm{t}, 2 \mathrm{H}, J=7.5 \mathrm{~Hz}), 2.96(\mathrm{~s}, 1.4 \mathrm{H}), 3.14(\mathrm{~s}, 1.6 \mathrm{H})$, 3.34-3.46 (m, 1H), 3.56-3.81 (m, 6H), 3.94-4.00 (m, 1H). ${ }^{13} \mathrm{C}$ NMR (300 MHz, $\left.\mathrm{CD}_{3} \mathrm{OD}\right)$ :

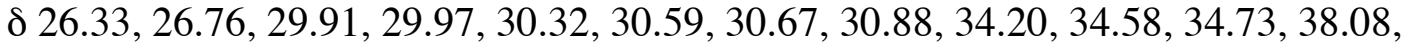
52.63, 54.02, 64.79, 71.15, 71.60, 72.38, 72.93, 73.05, 73.15, 73.70, 74.18, 176.73, 176.78, 197.69. HRMS (ESI) calculated for $\mathrm{C}_{20} \mathrm{H}_{39} \mathrm{NO}_{7} \mathrm{SNa}\left(\mathrm{M}+\mathrm{Na}^{+}\right) m / e$ 460.2345, found 460.2354

11-Mercapto-undecanoic acid methyl-(2,3,4,5,6-pentahydroxy-hexyl)-amide (polyolAT) A solution of 7 (200 mg, $0.457 \mathrm{mmol})$ in methanol $(2.00 \mathrm{~mL})$ was purged with nitrogen for 10 minutes. Ammonia ( $2 \mathrm{M}$ in methanol, $456 \mu \mathrm{L})$ was added and the reaction mixture was stirred for $12 \mathrm{~h}$ under nitrogen. The reaction was quenched using Amberlyst IR-1200 acidic resin. The resin was added until the $\mathrm{pH}$ was neutral. The resin was filtered, the solvent was removed with a rotatory evaporator under reduced pressure and 
reaction mixture was purified by silica gel chromatography (eluent $5 \% \rightarrow 7 \% \rightarrow 10 \% \rightarrow$ $15 \%$ methanol in dichloromethane) to yield Polyol-AT as a white solid (80.0 mg, 0.202 mmol, 44\%). ${ }^{1} \mathrm{H}$ NMR (300 MHz, $\left.\mathrm{CD}_{3} \mathrm{OD}\right): \delta$ 1.27-1.44 (m, 12H), 1.54-1.66 (m, 4H), $2.39(\mathrm{t}, 1 \mathrm{H}, J=7.6 \mathrm{~Hz}), 2.44-2.52(\mathrm{~m}, 3 \mathrm{H})$ \{most likely 2 overlapped signals: $2.48(\mathrm{t}, 1 \mathrm{H}$, $\left.J=7.6 \mathrm{~Hz},-\mathrm{CH}_{2} \mathrm{CH}_{2} \mathrm{C}(\mathrm{O}) \mathrm{N}\right)$ and $\left.2.49\left(\mathrm{t}[111 \mathrm{t}], J=7 \mathrm{~Hz}, J_{\mathrm{HD}}=1 \mathrm{~Hz},-\mathrm{CH}_{2} \mathrm{CH}_{2} \mathrm{SD}\right)\right\}, 2.96(\mathrm{~s}$, $1.4 \mathrm{H}), 3.14(\mathrm{~s}, 1.6 \mathrm{H}), 3.34-3.46(\mathrm{~m}, 1 \mathrm{H}), 3.56-3.81(\mathrm{~m}, 6 \mathrm{H}), 3.93-4.01(\mathrm{~m}, 1 \mathrm{H}) .{ }^{13} \mathrm{C} \mathrm{NMR}$ (300 MHz, $\left.\mathrm{CD}_{3} \mathrm{OD}\right): \delta 25.11,26.35,26.77,29.56,30.35,30.62,30.72,30.765,34.22$, 34.60, 34.72, 35.38, 38.13, 52.68, 54.03, 64.87, 71.26, 71.69, 72.41, 73.03, 73.10, 73.19, 73.73, 74.26, 176.77, 176.85. HRMS (ESI) calculated for $\mathrm{C}_{18} \mathrm{H}_{36} \mathrm{NO}_{6} \mathrm{~S}\left([\mathrm{M}-\mathrm{H}]^{-}\right) m / e$ 394.2263, found 394.2281.

[2-(2-\{2-[2-(11-Mercapto-undecyloxy)-ethoxy]-ethoxy\}-ethoxy)-ethoxy]-acetic acid (PEG acid-AT) A solution of compound 4 (100 mg, $0.196 \mathrm{mmol})$ in methanol/THF (1:1) $(4 \mathrm{~mL})$ was purged with nitrogen for $10 \mathrm{~min}$. Aqueous $\mathrm{LiOH}(1 \mathrm{M})$ was purged with $\mathrm{N}_{2}$ for $5 \mathrm{~min}$ and then added $(486 \mu \mathrm{L})$ to the THF solution. The resulting solution was purged for $5 \mathrm{~min}$ and stirred under nitrogen for $12 \mathrm{~h}$. To the reaction was added $1 \mathrm{~N} \mathrm{HCl}$ until the $\mathrm{pH}$ was 1 . A solution of brine-water $(1: 1)$ was added $(10 \mathrm{~mL})$ and the mixture was extracted with dichloromethane $(5 \times 20 \mathrm{~mL})$. Flash chromatography on silica gel (eluent $5 \% \rightarrow 10 \%$ methanol in dichloromethane with $0.5 \%$ acetic acid) yielded PEG acid-AT as colorless, viscous oil (60.5 mg, $0.138 \mathrm{mmol}, 70.4 \%) .{ }^{1} \mathrm{H}$ NMR (300 MHz, $\left.\mathrm{CDCl}_{3}\right): \delta 1.22-1.40(\mathrm{~m}, 15 \mathrm{H}), 1.51-1.65(\mathrm{~m}, 4 \mathrm{H}), 2.52(\mathrm{q}, 2 \mathrm{H}, J=7.5 \mathrm{~Hz}), 3.45(\mathrm{t}, 2 \mathrm{H}$, $J=7 \mathrm{~Hz}), 3.55-3.77(\mathrm{~m}, 16 \mathrm{H}), 4.15$ (s, 2H), 8.2-9.1 (br s, 1H). ${ }^{13} \mathrm{C}$ NMR $(300 \mathrm{MHz}$, $\left.\mathrm{CDCl}_{3}\right): \delta 24.82,26.21,28.53,28.69,29.14,29.23,29.40,29.68,34.21,69.19,70.06$, 70.47, 70.56, 70.66, 70.74, 71.40, 71.70, 172.82. HRMS (ESI) calculated for $\mathrm{C}_{21} \mathrm{H}_{41} \mathrm{O}_{7} \mathrm{~S}$ $\left([\mathrm{M}-\mathrm{H}]^{-}\right) \mathrm{m} / \mathrm{e} 437.2573$, found 437.2552 .

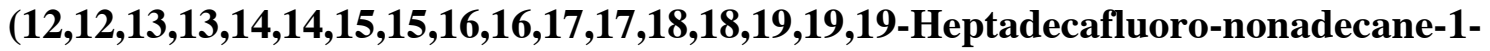
thiol) (Fluoro-AT) This synthesis was performed according to the procedure of Graupe et al. ${ }^{3}$ with the exception that $\mathrm{LiAlH}_{4}$ was used to reduce the alkyl-iodide and thioester moiety instead of the published $\mathrm{NaBH}_{4}$.

Solvophobicity Tests: Advancing contact angles were obtained for each of the surfaces with various solvents. Briefly, a small volume of solvent was added to the cleaned surfaces via syringe. As additional solvent was added the angle was measured through a magnifying bezel. Values from $180^{\circ}-90^{\circ}$ reflect a high degree of beading. As a benchmark, values for mixtures of water with polar-organic solvents were obtained for an undecanethiol SAM. (Fig. S2) A reduction in beading with increasing amount of organic solvent was observed. Polar organic solvents were chosen because these solvents dissolve most peptides and biologically active small molecules. Measured values for $100 \%$ DMSO and $50 \%$ DMF are $61^{\circ}$ and $72^{\circ}$ respectively. The fluoro-AT SAM was the most effective at beading these solvents; this surface gives values of $80^{\circ}$ and $92^{\circ}$ for $100 \% \mathrm{DMF}$ and 100\% DMSO respectively. 

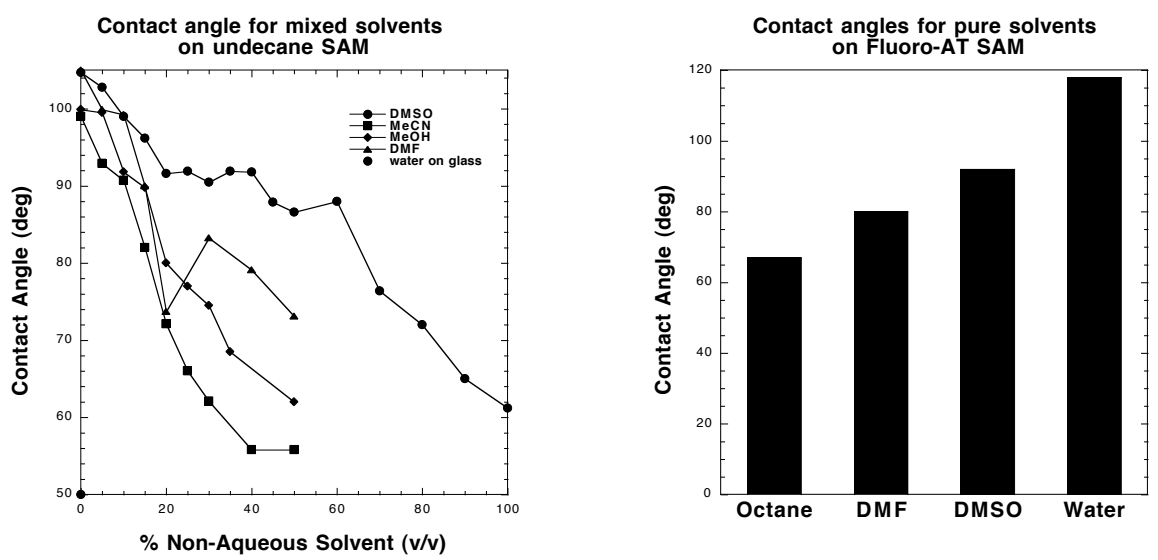

Figure S2. Contact angles of various solvents on hydrophobic SAMs. LEFT: Advancing contact angle of mixed polar-organic/aqueous solvents on an undecanethiol SAM. RIGHT: Advancing contact angle of neat solvents on fluoro-AT SAM.

To test the feasibility of spotting arrays with a hand held pipet, approximately 200 $\mathrm{nL}$ of water was spotted on the chips patterned with $750 \mu$ m hydrophillic PEG acid-AT squares surrounded by fluoro-AT SAM background. The water clearly formed beads due to the high contact angle between the solvent and the fluorinated surface. (Fig. S3).

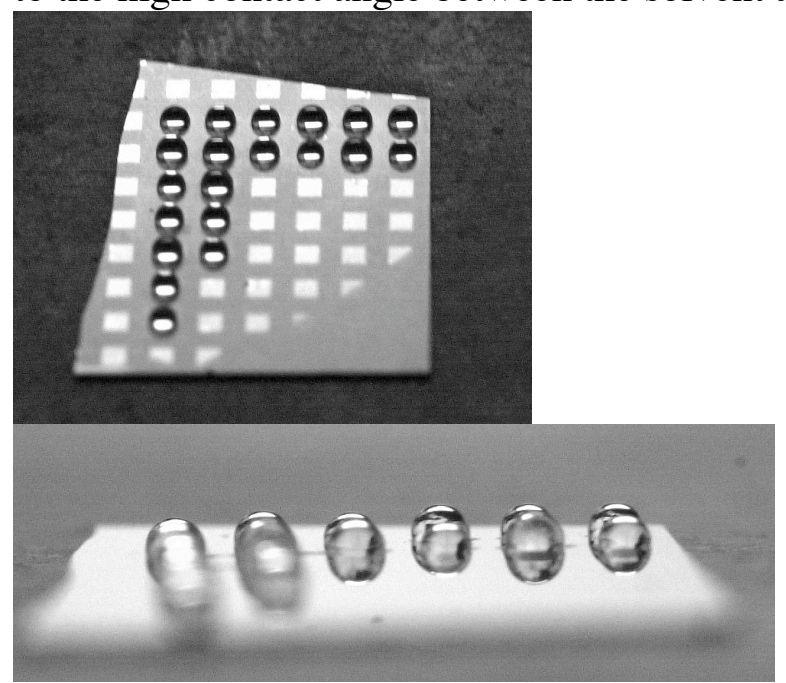

Figure S3. Image of $200 \mathrm{nl}$ water droplets on a patterned SAM chip with a fluoro-AT SAM background and PEG acid-AT SAM $750 \mu \mathrm{m}$ squares. TOP: Top view. Note: The contrast between the two surfaces is visible due to the selective condensation of water on the hydrophilic PEG acid-AT surface. Easy visualization further simplifies the array production.

The importance of high contact angles of the background is reflected in that increased beading allows a high density of spots on a single chip. The higher the contact angle, more spots can be fit on the chip. A simple geometric rational shows that the contact radius $(\rho)$ of the liquid drop with volume $(\mathrm{V})$ depends on the surface contact angle $(\theta)$ as 
$\rho=\sin ^{-1} \theta[(\pi / 3 \mathrm{~V})(1-\cos \theta)(2+\cos \theta)]^{-1 / 3}$

No gravity or surface tension effects are included in this analysis. See Fig. S4 for the $\rho$ vs. $\theta$ plot.

It is evident that the effective size (physical size) of a spot no longer changes for contact angles above $90^{\circ}$. (Fig. S4) The relevance of the solvophobicity of the fluoro-AT SAM background is that it provides contact angles above or near to $90^{\circ}$ for a wider range of solvents than other hydrophobic surfaces (Fig. S2) and is also cytophobic (vide infra).

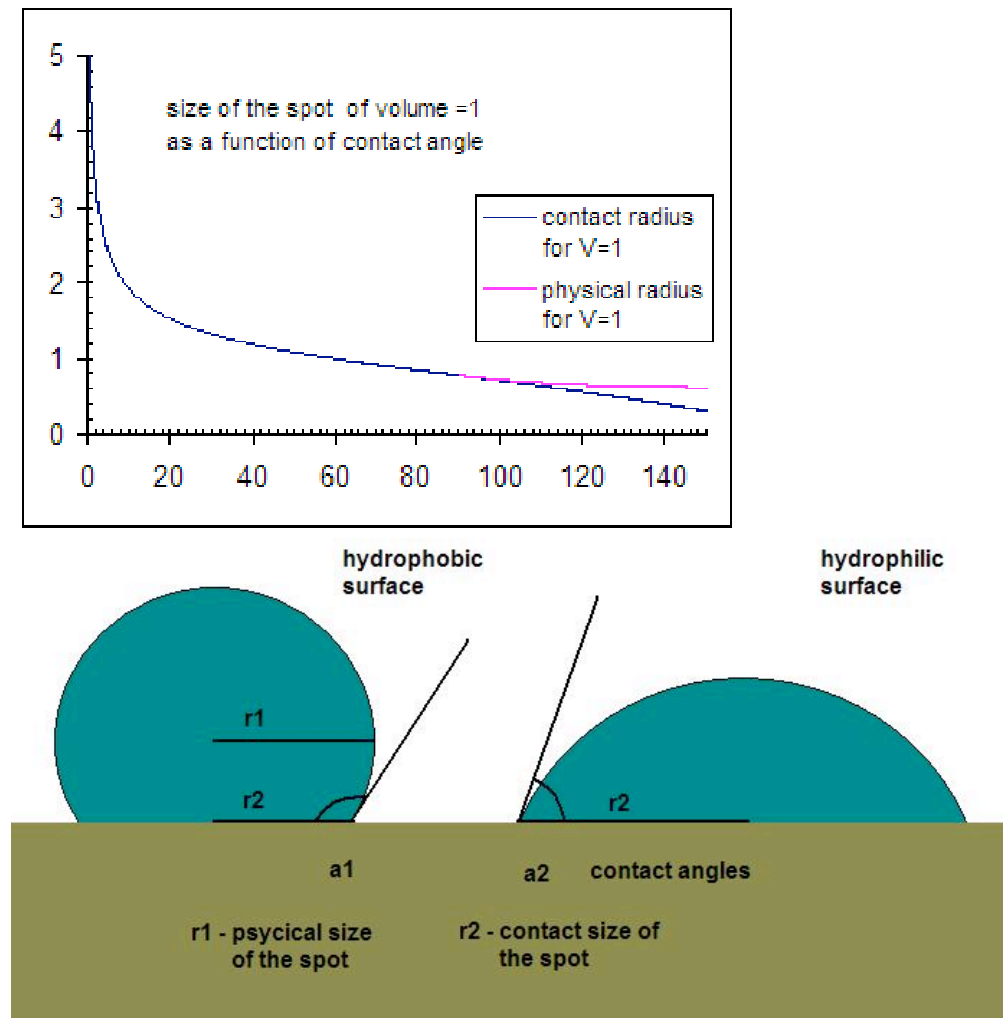

Figure S4. The contact angle between a solvent drop with the surface controls the potential feature density of the array. TOP: Size of spot (solvent drop) with constant volume as a function of contact angle. Bottom: Graphical explanation of "contact radius" and "physical radius."

General Preparation of the Arrays of Self-Assembled Monolayers (Assembly After Conjugation Strategy): Chromium $(1 \mathrm{~nm})$ and then gold $(25 \mathrm{~nm})$ were evaporated onto piranha-cleaned glass coverslips (Corning No 1 1/2, $23 \mathrm{~mm}$ squares) using a thermal evaporator (Denton Vacuum, Moorestown, NJ). Substrates were immediately immersed into a $1 \mathrm{mM}$ solution of fluoro-AT in absolute ethanol. After $24 \mathrm{~h}$ substrates were thoroughly rinsed with ethanol and dried under a stream of nitrogen. Coverslips with fluoro-AT SAM were irradiated with UV-light (1 kW, Hg-Xe Research Arc Lamp, Oriel Instruments (Spectra-Physics, Stratford, CT) through a quartz photomask (array of 500 $\mu \mathrm{m}$ or $750 \mu \mathrm{m}$ squares, 0.067 quartz-chromium mask (Photo Sciences, Torrance, CA) for $1 \mathrm{~h}$. Irradiated samples were rinsed thoroughly using several repetitive washes with absolute ethanol and distilled water and dried under a steam of nitrogen. Spotting of alkanethiol solutions onto the bare gold areas was performed within $2 \mathrm{~h}$ of the 
photolithography. Spotting was performed manually using a P2-Pipetman (Gilson) in a humidity chamber. Spotted arrays were stored in the humidity chamber for $12 \mathrm{~h}$ and thoroughly washed using repeated washes with ethanol and water. Rapid flow during washing was used to prevent cross-contamination of array spots.

Cell Culture: The neuroblastoma cell line, SH-SY5Y, was grown in 10\% heatinactivated fetal bovine serum (HI FBS), 45\% high glucose Dulbecco's modified Eagle medium (DMEM), 45\% Ham's F12 nutritional supplement (F12) with penicillin and streptomycin in an atmosphere of $5 \% \mathrm{CO}_{2}$ at $37^{\circ} \mathrm{C}$. The fibroblast line Swiss 3T3 was propagated in $10 \% \mathrm{HI}$ FBS in DMEM. For plating of the cells on the chips, cells were incubated at $37{ }^{\circ} \mathrm{C}$ with $5 \%$ trypsin/ethylenediamine-tetraacetic acid (EDTA), centrifuged and resuspended in media at $2 \times 10^{5}$ cells $/ \mathrm{mL}$ and $5 \times 10^{5}$ cells $/ \mathrm{mL}$ for the fibroblasts and neuroblastomas respectively. Chips were sterilized by placing each in a single well of a 6well plate, soaking in 70\% ethanol, and drying under UV light for $1 \mathrm{~h}$. To the individual chips was added $3 \mathrm{~mL}$ of the cell suspensions to each well. After 2-5 h, the media was gently replaced three times and the chips were picked up, transferred to a clean well and 3 $\mathrm{mL}$ of media was added. The cells on the chips were typically propagated between 1-7 days. The media was then removed, and the cells were fixed in PFA buffer ( $2 \%$ paraformaldehyde, $350 \mathrm{mM} \mathrm{NaCl}, 150 \mathrm{mM}$ HEPES, $10 \mathrm{mM} \mathrm{CaCl}_{2}, \mathrm{pH}$ 7.4) for $20 \mathrm{~min}$ at $0{ }^{\circ} \mathrm{C}$. The cells were washed twice with Dulbecco's phosphate buffered saline and stained (0.1\% Coomassie Brilliant Blue in $\mathrm{H}_{2} \mathrm{O} / \mathrm{MeOH} / \mathrm{AcOH}(50: 50: 1)$ ) for 5-15 min after which the cells were washed twice with water and air dried. Images were generated on a Leica MZ6 dissecting microscope.

Human Embryonic Stem Cell Propogation and Plating: The human ES cell line, H1, was grown on matrigel-coated plates in mouse embryonic fibroblast (MEF)-conditioned media (CM) supplemented with $4 \mathrm{ng} / \mathrm{mL}$ basic fibroblast growth factor (bFGF). To produce CM, MEFs were seeded at a density of $2.12 \times 10^{5}$ cells $/ \mathrm{mL}$ and fed medium consisting of DMEM/F12, 20\% Knockout $^{\mathrm{TM}}$ serum replacement, $2 \mathrm{mM}$ L-glutamine, $1 \%$ minimal essential media nonessential amino acids, $0.1 \mathrm{mM} \beta$-mercaptoethanol. Both cell lines ( $\mathrm{H} 1$ and $\mathrm{MEF}$ ) were maintained at $37^{\circ} \mathrm{C} / 5 \% \mathrm{CO}_{2}$ with $\mathrm{CM}$ collected and cells fed approximately every $24 \mathrm{~h}$. Cell suspensions were made by treating with collagenase IV (1 $\mathrm{mg} / \mathrm{mL}$ ) for 10-12 min. The cells were scraped from the surface and suspended in CM.

Chips were sterilized as per the other cell line. To aid in ES cell patterning, the chips were then soaked in DMEM/F12 with 15\% defined FBS for 1-2 $\mathrm{h}$ and washed thoroughly. Then cells were plated on each chip (1-2 x 10 cells/chip) and allowed to incubate overnight. The next morning the chips were moved to fresh wells and fed with CM.

Test for alkaline phosphatase activity. The procedure for staining for alkaline phosphatase activity was essentially identical to the procedure supplied by the manufacturer. After propagation of the ES cells, the media was removed. The reagents in $100 \mathrm{mM}$ Tris $\mathrm{pH} 8.5$ were incubated with the chips for $30 \mathrm{~min}$ at $25^{\circ} \mathrm{C}$. The chips were washed gently for 5 min with Tris buffer and then fixed and dried as usual. 
Initial experiments to test fluoro-AT SAM cytophobicity and cell patterning. Chips with a fluoro-AT SAM background and PEG acid-AT squares fabricated by immersion (vide supra) were plated with both SH-SY5Y neuroblastoma and Swiss-3T3 fibroblast cells which were either imaged as live cells or as fixed and stained cells (vide supra). For both cell types, dense squares of cells on the cytophilic surface were formed. A minimal number of cells growing on the background were observed thereby demonstrating the cytophobic property of the fluoro-AT SAM background. (Fig. S5)

\section{Swiss 3 T3}
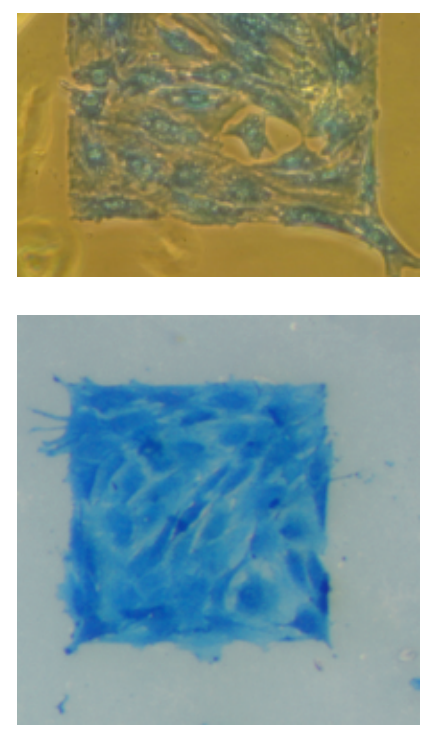

\section{SH-SY5Y}
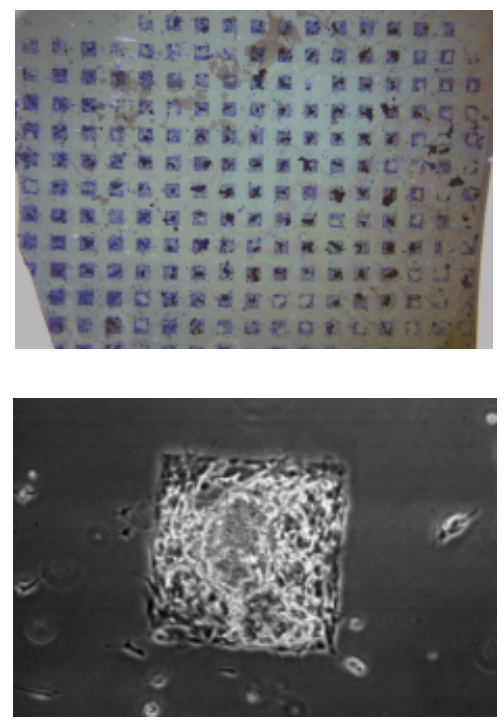

Figure S5. Fluoro-AT SAMs are cytophobic and they can readily be patterned. The chips have PEG acid-AT SAMs with fluoro-AT SAM background between the features. LEFT: Swiss 3 T3 fibroblasts were fixed and stained. Note cells growing out of feature at the corner. ${ }^{4,5}$ RIGHT: SH-SY5Y neuroblastoma cells. Top: Cells were fixed and stained. Bottom: Phase contrast image of live cells.

Initial experiments to test cell response to SAM formation by spotting. A chip with a fluoro-AT SAM background surrounding bare gold squares was formed by photolithography (vide supra). To this was spotted an aqueous solution (1 mM) of cytophillic PEG acid-AT in a pattern of $3 \times 3$ squares. An ethanolic solution of fluoro-AT was spotted on the remaining bare gold squares. Neuroblastoma SH-SY5Y cells were plated, proliferated, fixed, and stained. A pattern corresponding to cells affixed to only the expected cytophillic surface was evident as was minimal binding to the cytophobic surface (Fig. S6). This result demonstrates that spotting solutions of ATs can generate both cytophilic and cytophobic SAMs. 


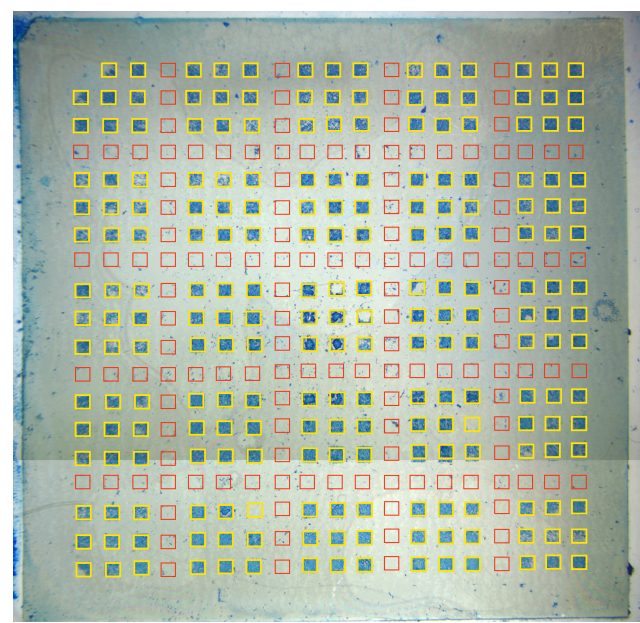

Figure S6. The cytophobicity, cytophilicity and patternability of SAMs formed by spotting. A solution of cytophilic PEG acid-AT was spotted in features of 3x3 squares (yellow). Between these squares was spotted a solution of fluoro-AT (red). The area between features is a fluoro-AT SAM formed by emersion. SH-SY5Y cells were plated, fixed, and stained. This image is a composite as indicated by the horizontal line near the bottom of the chip.

\section{References}

(1) Houseman, B. T.; Mrksich, M. J. Org. Chem. 1998, 63, 7552.

(2) Pale-Grosdemange, C.; Simon, E.S.; Prime, K.L.; Whitesides, G.M. J. Am. Chem. Soc. 1991, 113, 12.

(3) Graupe, M.; Koini, T.; Wang, V. Y.; Nassif, G. M.; Colorado, R.; Villazana, R. J.; Dong, H.; Miura, Y. F.; Shmakova, O. E.; Lee, T. R. J. Fluorine Chem. 1999, 93, 107.

(4) Parker, K. K.; Brock, A. L.; Brangwynne, C.; Mannix, R. J.; Wang, N.; Ostuni, E.;

Geisse, N. A.; Adams, J. C.; Whitesides, G. M.; Ingber, D. E. FASEB J. 2002, 16. 1195. (5) Brock, A.; Chang, E.; Ho, C-C.; LeDuc, P.; Jiang, X.; Whitesides, G. M.; Ingber, D. E. Langmuir 2003, 19, 1611. 